\title{
Primary characterization of the immune response in pigs infected with Trichinella spiralis
}

\author{
Nan Wang ${ }^{1 \dagger}$, Xue Bai $^{1 \dagger}$, Bin Tang ${ }^{1 \dagger}$, Yong Yang ${ }^{1}$, Xuelin Wang ${ }^{1 \dagger}$, Hongfei Zhu ${ }^{2}$, Xuenong Luo ${ }^{3}$, Hongbin Yan ${ }^{3}$, \\ Hong Jia ${ }^{2}$, Mingyuan Liu ${ }^{1 *}$ and Xiaolei Liu ${ }^{1 *}$
}

\begin{abstract}
Trichinellosis, which is caused by Trichinella spiralis (T. spiralis), is a serious zoonosis. Pigs play an important role in the transmission of human trichinellosis. Characterizing the immune response to T. spiralis infection is key to elucidating host-parasite interactions. However, most studies on the immune response to T. spiralis infection have employed murine models. In this study, we investigated the immune response to T. spiralis infection in pigs. The results showed that the average numbers of larvae per gram (lpg) for the 100-muscle larvae (ML), 1000-ML, and 10 000-ML groups were 1.502, 35.947, and 398.811, respectively. The percentages of CD3+T cells, B cells, CD4+ T cells, Treg cells, and Th17 cells were elevated in the infection groups compared to the control animals. In contrast, CD8+ T cell percentages were reduced after infection in the low-dose group. The number of neutrophils was increased at 3-17 days post-infection (dpi). Th1 cytokine IL-2 levels were significantly decreased at $7 \mathrm{dpi}$, and Th2 cytokine IL-4 levels were significantly elevated at $3 \mathrm{dpi}$. Treg cytokine IL-10 levels were significantly elevated between $7 \mathrm{dpi}$ and $30 \mathrm{dpi}$. Th17 cytokine IL-17A levels were significantly increased beginning at $11 \mathrm{dpi}$. These results confirmed that pigs infected with T. spiralis predominantly induced Th2 and Treg immune responses, which suppress the Th1 immune responses. This study provides novel insights into the immune response of pigs infected with T. spiralis.
\end{abstract}

\section{Introduction}

Trichinellosis is a frequently occurring zoonosis that leads to significant economic loss in pork production. This disease is distributed worldwide and has a notable impact on human health, with approximately 10000 cases occurring each year [1]. The main causative agent of trichinellosis, Trichinella spiralis (T. spiralis), is usually undetected in pig carcasses due to the lack of macroscopically visible alterations, and pigs play an important role in the transmission of human trichinellosis [2-4]. Humans become infected via consumption of inadequately cooked or raw meat (usually pork) containing

\footnotetext{
*Correspondence: liumy36@163.com; liuxlei@163.com

${ }^{\dagger}$ Nan Wang, Xue Bai and Bin Tang contributed equally to this work

${ }^{1}$ Key Laboratory of Zoonosis Research, Ministry of Education,

Institute of Zoonosis/College of Veterinary Medicine, Jilin University, Changchun 130000, China

Full list of author information is available at the end of the article
}

infective T. spiralis larvae [5-7]. After ingestion, infective muscle larvae (ML) exhibit 4 molting events in the intestinal epithelium [8]. Then, the worms develop into adult worms (Ad) and released newborn larvae (NBL), and NBL finally penetrate into the muscle cells, where they grow, transforming the host cells into nurse cells, and develop into ML $[5,9]$. To resist the invasion of parasites, the innate and adaptive immune responses of the host are activated and undergo the process of expulsion. In human trichinellosis, the cellular immune response produces a mixed Th1/Th2 immune response with Th2 predominance during the chronic stage [10]. A type 2 cytokine pattern was produced by peripheral blood mononuclear cells (PBMC) of the patient, and the share of CD8+ lymphocytes in the PBMC composition was increased [11]. In rodent models, a stable Th2 immune response is maintained during infection with $T$. spiralis after a short Th1 immune response [12]. However, the

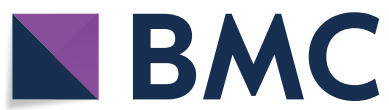

(c) The Author(s) 2020. This article is licensed under a Creative Commons Attribution 4.0 International License, which permits use, sharing, adaptation, distribution and reproduction in any medium or format, as long as you give appropriate credit to the original author(s) and the source, provide a link to the Creative Commons licence, and indicate if changes were made. The images or other third party material in this article are included in the article's Creative Commons licence, unless indicated otherwise in a credit line to the material. If material is not included in the article's Creative Commons licence and your intended use is not permitted by statutory regulation or exceeds the permitted use, you will need to obtain permission directly from the copyright holder. To view a copy of this licence, visit http://creativeco mmons.org/licenses/by/4.0/. The Creative Commons Public Domain Dedication waiver (http://creativecommons.org/publicdomain/ zero/1.0/) applies to the data made available in this article, unless otherwise stated in a credit line to the data. 
cellular immune response in pigs infected with $T$. spiralis is not well known.

The immune response and gene expression in the host and parasite metabolism are switched on at different developmental stages $[9,13,14]$. The parasite can evade the host immune defenses to survive through the cuticle and secretory proteins that regulate the immune response and form nurse cells $[13,15,16]$. A previous study showed that $T$. spiralis infection modulates several signaling pathways in infected animals such that the worms can persistently exist for several years within the host [13]. The regulatory immune response of hosts has a positive effect on the survival of the parasite. A subset of $\mathrm{T}$ lymphocytes, the CD4+ T cells, plays a key role in parasitic infection and can polarize into Th1, Th2, Treg, and Th17 cells upon antigenic stimulation. T. spiralis and its secretory products can suppress inflammatory responses and induce Th2-type immune responses, as determined by the elevated Th2-associated cytokine levels observed in infected animals $[17,18]$. The Th1 phenotype immune response is induced during the intestinal stage and predominantly induces a Th2-type immune response during the ML phase [19]. The role of the Th1-type immune response contributes to parasites elimination [20]. Th2type immune responses may help alleviating tissue damage and strengthen tissue repair [21]. Treg-type immune responses play a key role in the anti-inflammatory effects of helminth infection and exist in the ML phase [22, 23]. The percentage of Th17 cells is significantly higher in the immunopathology of human schistosomiasis [24]. Th17 cells produce the proinflammatory cytokine IL-17, which plays a role in intestinal inflammation [25]. IL-17 levels are increased during the acute phase of $T$. spiralis infection and are associated with jejunal muscle contractility in mice [26]. In summary, Th1, Th2, Treg, and Th17 cells play important roles in the infection of T. spiralis. Therefore, we studied the dynamics of $\mathrm{T}$ lymphocytes in pigs infected with T. spiralis.

$B$ cells are a major component of the systemic immune response in hosts. B cells play a key role in parasite clearance by producing antibodies [27]. Meanwhile, B cells are important antigen-presenting cells (APCs) that can induce Treg cell production [28]. Neutrophils are essential components in the innate immune responses of the host and play important roles in local immunity during infection by promoting inflammation and fighting infections [29]. Neutrophils can regulate adaptive immune responses by inhibiting or promoting $\mathrm{T}$ cell proliferation, depending on activation status $[30,31]$.

Previous studies have frequently used mice as animal models in research investigating the immune response to trichinellosis, although T. spiralis was isolated from pigs $[32,33]$. To better understand the whole process of immune responses in pigs infected with $T$. spiralis, this study was performed to analyze the dynamics of $\mathrm{T}$ cells, B cells, neutrophils, and cytokines associated with Th1, Th2, Treg, and Th17 cells during T. spiralis infection in pigs. This study is the first to present a detailed kinetic analysis of the immune response in $T$. spiralis infection in pigs. It is important to understand the immunology and pathology of T. spiralis.

\section{Materials and methods \\ Parasites and animals}

The Chinese T. spiralis Henan isolate (ISS534) used in this study was maintained through serial passage in Sprague-Dawley (SD) rats in our laboratory. ML was recovered from the rats infected for more than 30 days post-infection (dpi) by the standard HCL-pepsin artificial digestion method [34]. SD rats and large white pigs were obtained from the Experimental Animal Center of Norman Bethune University of Medical Science (NBUMS), China. All pigs were healthy and were fed a basic diet without any antibiotics. Before the experiment, all pigs underwent routine blood examination, and fecal samples were tested for other parasite eggs by the flotation and sedimentation method. The pigs were kept in a standard pig house in our laboratory under the care of a professional breeder.

All experiments in this study were conducted according to the regulations of the Administration of Affairs Concerning Experimental Animals in China. The procedure of animal experiments was approved by the Institutional Animal Care and Use Committee of Jilin University (Permit No. 20170318).

\section{Experimental infection}

A total of 12 female large white pigs, aged 10 weeks, were randomly divided into 4 groups, in which 3 infected groups were experimentally inoculated with 100 (low-dose group), 1000 (middle-dose group) and 10 000 (high-dose group) ML of T. spiralis by oral administration. Another control group was administered $0.9 \%$ $\mathrm{NaCl}$ solution orally. Serum was collected at $0,3,7,11$, $17,30,45$, and $60 \mathrm{dpi}$ via centrifuging blood samples at $3000 \mathrm{~g}$ for $30 \mathrm{~min}$ at $4{ }^{\circ} \mathrm{C}$, before storage at $-80^{\circ} \mathrm{C}$ until use. The pigs infected with $T$. spiralis were euthanized at $60 \mathrm{dpi}$, and 50-100 g samples of six different muscle tissue (tongue, shoulder, flexor, diaphragm, gluteus, and gastrocnemius) were necropsied to calculate the average numbers of larvae per gram (lpg) by digestion method. For the detection of other endoparasites, the stomach, intestine and offal of all pigs were examined at necropsy. The fecal samples were tested for other parasite eggs by the flotation and sedimentation method. 


\section{Flow cytometry}

The relative ratios of CD4+ and CD8+ T cells, $\mathrm{T}$ cells, B cells, neutrophils, Treg cells, and Th17 cells in peripheral blood were analyzed by flow cytometry. Whole blood samples were obtained from the jugular vein via aspiration as described above. Cells were isolated using red blood cell lysis buffer (Solarbio, Beijing, China) as follows: $200 \mu \mathrm{L}$ anticoagulation blood was treated with $600 \mu \mathrm{L}$ red blood cell lysis buffer for $10 \mathrm{~min}$, centrifuged at $1000 \mathrm{~g}$ for $5 \mathrm{~min}$ and discarded from the supernatant. Harvested cells were resuspended in $100 \mu \mathrm{L}$ cold PBS (phosphate buffered saline, $\mathrm{pH}$ 7.2) and then treated for surface and intracellular staining. For surface staining, the following antibodies against surface markers were used according to the manufacturer's instructions: $2 \mu \mathrm{L}$ mouse anti-porcine CD3e-APC (SouthernBiotech, Birmingham, AL, USA), $2 \mu \mathrm{L}$ mouse anti-porcine CD4-PE (SouthernBiotech), and $2 \mu \mathrm{L}$ mouse anti-porcine CD8aFITC (SouthernBiotech) were used to label CD4+ T cells and CD8+ T cells at $4{ }^{\circ} \mathrm{C}$ for 30 min in the dark; $2 \mu \mathrm{L}$ mouse anti-porcine CD3e-APC and $2 \mu \mathrm{L}$ mouse anti-porcine CD21-FITC (SouthernBiotech) were used to label $\mathrm{T}$ and B cells at $4{ }^{\circ} \mathrm{C}$ for $30 \mathrm{~min}$ in the dark; $10 \mu \mathrm{L}$ mouse anti-pig CD14-FITC (Bio-Rad, Hercules, CA, USA), $10 \mu \mathrm{L}$ mouse anti-pig SWC8 (swine workshop cluster number 8; Bio-Rad), and $1 \mu \mathrm{L}$ goat anti-mouse IgM-PE (SouthernBiotech) were used to label neutrophils at $4{ }^{\circ} \mathrm{C}$ for $30 \mathrm{~min}$ in the dark; $2 \mu \mathrm{L}$ mouse anti-porcine CD4$\mathrm{PE}$ and $2 \mu \mathrm{L}$ mouse anti-pig CD25-FITC (Bio-Rad) were used for surface labeling of Treg cells at $4{ }^{\circ} \mathrm{C}$ for $30 \mathrm{~min}$ in the dark; and $2 \mu \mathrm{L}$ mouse anti-porcine CD3e-APC and $2 \mu \mathrm{L}$ mouse anti-porcine CD4-PE were used for surface labeling of Th 17 cells at $4{ }^{\circ} \mathrm{C}$ for $30 \mathrm{~min}$ in the dark. Intracellular staining is required to determine the percentage of Treg and Th17 cells. Next, treatment with $5 \mu \mathrm{L}$ rat anti-pig FOXP3-APC (eBioscience, San Diego, CA, USA) and $5 \mu \mathrm{L}$ mouse anti-pig IL-17A-FITC (Mabtech AB, Stockholm, Sweden) were performed at $4{ }^{\circ} \mathrm{C}$ for $30 \mathrm{~min}$ in the dark following the surface-stained cells fixed and permeabilized with FIX/PERM set (BD Biosciences, San Jose, CA, USA) according to the manufacturer's instructions. After incubation with antibodies, all stained cells were washed three times with $500 \mu \mathrm{L}$ cold PBS to remove unbound antibodies. Next, the stained cells were resuspended in $200 \mu \mathrm{L}$ cold PBS, and the percentage of the stained cells in peripheral blood was examined using a FACSCalibur flow cytometer (BD Biosciences). Data were analyzed using FlowJo software (BD Biosciences).

\section{Cytokine assay}

The levels of Th1 (IL-2), Th2 (IL-4), and Treg (IL-10, TGF $-\beta_{1}$ ) cytokines in serum samples at the same time as above were quantified by commercially available ELISA Kits (R\&D Systems, Minneapolis, MN, USA) according to the manufacturer's instructions. Th17 cytokine IL-17A was measured using a commercially available ELISA Kit (Invitrogen, Carlsbad, CA, USA). The concentrations of each cytokine were extrapolated from the standard curve constructed using recombinant porcine cytokines [35].

\section{Statistical analysis}

Statistical analysis was performed using GraphPad Prism 5.0 software for Windows. All data are presented as the mean \pm standard error of the means (SEM) of three independent experiments. The two-way ANOVA test was used to analyze the differences between experimental groups. Values of $* P<0.05,{ }^{* *} P<0.01$, and ***:P $P 0.001$ were regarded as statistically significant.

\section{Results}

\section{Larvae densities and distribution of $T$. spiralis infection} in pigs

In pigs inoculated with different doses of T. spiralis for 60 dpi, larvae densities and distribution in muscle are shown in Table 1. All muscle tissue obtained from infected pigs was larvae-positive. The numbers of larvae in muscle increased in an infective dose-dependent manner with average lpg values of 1.502, 35.947, and 398.811 for pigs infected with 100-ML, 1000-ML, and 10 000-ML doses of $T$. spiralis, respectively. With higher infective doses, the reproductive capacity index (larvae recovered/larvae inoculated, RCI) was higher than that of the low-infective-dose group. In different infective doses, ML were mainly localized to the tongue and diaphragm. All the pigs were in the normal range of leukocytes and eosinophils before the experiment. No gastrointestinal parasites or eggs were found in any of the experimental pigs.

Table 1 Intensity of Ipg in muscles of pigs infected with different doses of $T$. spiralis

\begin{tabular}{llll}
\hline Location/doses & \multicolumn{2}{l}{ LPG } & \\
\cline { 2 - 4 } & $\mathbf{1 0 0}$ & $\mathbf{1 0 0 0}$ & $\mathbf{1 0 0 0 0}$ \\
\hline Tongue & 3.339 & $\mathbf{7 9 . 5 5 4}$ & 782.52 \\
Shoulder & 1.001 & 25.156 & 316.657 \\
Flexor & 0.504 & 17.37 & 257.623 \\
Diaphragm & 3.528 & 70.298 & 726.636 \\
Gluteus & 0.266 & 13.284 & 179.011 \\
Gastrocnemius & 0.371 & 10.02 & 130.42 \\
Mean & 1.502 & 35.947 & 398.811 \\
\hline
\end{tabular}




\section{Polarization and changes in the proportions of T cell subsets}

The proportions of $\mathrm{T}$ cell subsets in the peripheral blood of pigs infected with $T$. spiralis were measured. In different infective doses, the total number of CD3+ $\mathrm{T}$ cells was slightly elevated in the infection group compared with the control animals after infection but was restored at $45 \mathrm{dpi}$, as shown in Figure 1.

The results presented in Figure 2 demonstrate that the proportions of $\mathrm{CD} 4+\mathrm{T}$ cells peaked at $3 \mathrm{dpi}$ and were lower than the control group after $45 \mathrm{dpi}$. Instead, CD8 $+\mathrm{T}$ cells were reduced in the low-dose group, and the minimum value was observed at $11 \mathrm{dpi}$ (Figure 2A). In the middle-dose group, CD8+ $\mathrm{T}$ cells were reduced at $7 \mathrm{dpi}, 11 \mathrm{dpi}$, and $60 \mathrm{dpi}$ (Figure 2B). In the high-dose group, the CD8 $+\mathrm{T}$ cell population was increased after infection (Figure 2C). The ratio of $\mathrm{CD} 4+/ \mathrm{CD} 8+\mathrm{T}$ cells was elevated between $3 \mathrm{dpi}$ and $30 \mathrm{dpi}$ in the low-dose group, peaked at $3 \mathrm{dpi}$, and was restored at $45 \mathrm{dpi}$ (Figure 2A). In the middle- and high-dose groups, the ratio of $\mathrm{CD} 4+/ \mathrm{CD} 8+\mathrm{T}$ cells was elevated between $3 \mathrm{dpi}$ and $17 \mathrm{dpi}$, peaked at $7 \mathrm{dpi}$ and $3 \mathrm{dpi}$, and decreased at $45 \mathrm{dpi}$ (Figures $2 \mathrm{~B}$ and $\mathrm{C}$ ).

A subset of CD4+ T cells, the Treg cells, plays a key role in regulating the host immune response. As shown in Figure 3, at different infective doses, the relative percentages of Treg cells were elevated in the infection group compared with the control animals after $7 \mathrm{dpi}$ and peaked at $11 \mathrm{dpi}, 45 \mathrm{dpi}$, and $30 \mathrm{dpi}$. The number of Treg cells was significantly increased at $11 \mathrm{dpi}$ and $45 \mathrm{dpi}$ in the low-dose group (Figure 3A) and at $30 \mathrm{dpi}$ in the high-dose group (Figure $3 \mathrm{C}$ ).

Another subset of CD4+T cells, the Th17 cells, also participates in the host immune response. The results shown in Figure 4 indicate that the proportion of Th17 cells was significantly increased between $7 \mathrm{dpi}$ and $17 \mathrm{dpi}$ in pigs infected with $100 \mathrm{~T}$. spiralis, peaked at $11 \mathrm{dpi}$ and decreased to normal levels as in control animals at $45 \mathrm{dpi}$ (Figure 4A). For the other two infection groups, the proportions of Th17 cells were slightly increased after infection (Figures 4B and C). It is worth noting that the level of increase in Th17 cells was weakened as the infective dose increased.

\section{Changes in the proportions of B cells}

$B$ cells are a major component of the adaptive immune response that can eliminate pathogen infection by producing antibodies and controlling or enhancing $T$ cell function. The results demonstrate that the proportions of $\mathrm{B}$ cells were elevated in the low-dose infection group between 3 dpi and $30 \mathrm{dpi}$, peaked at $11 \mathrm{dpi}$ and were restored at $45 \mathrm{dpi}$ (Figure 1A). In the middle-dose group, B cells were elevated between $3 \mathrm{dpi}$ and $45 \mathrm{dpi}$, peaked at $17 \mathrm{dpi}$ with significant elevation, and were restored at $60 \mathrm{dpi}$ (Figure 1B). For the high-dose group, the dynamics of B cells were similar to those of the middle-dose group, but the B cell levels continued to increase until $60 \mathrm{dpi}$ and did not return to normal levels (Figure 1C). It should be noted that as the infective dose increased, the production and maintenance time of $\mathrm{B}$ cells also increased.

\section{Changes in the proportions of neutrophil populations}

Most granulocytes in peripheral blood are neutrophils, which play an important role in nonspecific immune defense by phagocytosis of foreign bodies. As shown in Figure 5 , the number of neutrophils in peripheral blood was slightly increased between $3 \mathrm{dpi}$ and $17 \mathrm{dpi}$ after infection with T. spiralis and peaked at $17 \mathrm{dpi}$, and the levels of neutrophils were lower than those in control animals at $45 \mathrm{dpi}$. The proportions of neutrophils increased with increasing infective dose.

\section{Serum cytokine expression}

To investigate CD4 $+\mathrm{T}$ cell differentiation, the expression levels of the cytokines associated with Th1, Th2, Treg, and Th17 immune responses were measured in serum by ELISA. The results shown in Figure 6 indicate that at the different infective doses, the levels of IL-2 decreased compared with healthy animals after infection and reached a minimum at $60 \mathrm{dpi}$. At the same time, the earliest significant reduction appeared at 7 dpi in the low-dose infection group (Figure 6A). The levels of IL-4 were significantly elevated between 3 dpi and $17 \mathrm{dpi}$ and peaked at $17 \mathrm{dpi}, 7 \mathrm{dpi}$, and $3 \mathrm{dpi}$ in the low-dose, middle-dose, and high-dose infection groups, respectively. In addition, IL-4 levels were lower than in healthy animals at $45 \mathrm{dpi}$, except for the high-dose infection group, which was decreased at $30 \mathrm{dpi}$ (Figure $6 \mathrm{~B}$ ). The levels of IL-10 were significantly elevated between $7 \mathrm{dpi}$ and $30 \mathrm{dpi}$, were restored at $60 \mathrm{dpi}$ and peaked at $11 \mathrm{dpi}, 30 \mathrm{dpi}$, and $30 \mathrm{dpi}$ in the low-dose, middle-dose, and high-dose infection groups, respectively (Figure 6C). There was no significant change in the expression of TGF- $\beta_{1}$ in pigs infected with T. spiralis (Figure 6D). The levels of IL-17A were significantly increased beginning at $11 \mathrm{dpi}$ in the low-dose, middledose, and high-dose infection groups, which peaked at $17 \mathrm{dpi}, 30 \mathrm{dpi}$, and $30 \mathrm{dpi}$, respectively. However, the IL-17A levels were restored at $45 \mathrm{dpi}$ and were lower than those of healthy animals at $60 \mathrm{dpi}$ in the low-dose infection group (Figure 6E).

\section{Discussion}

Characterizing the immune response processes is key to understand host-parasite interactions. T. spiralis ML could live in the host for various years, although the host immune system is activated to accelerate worm expulsion 


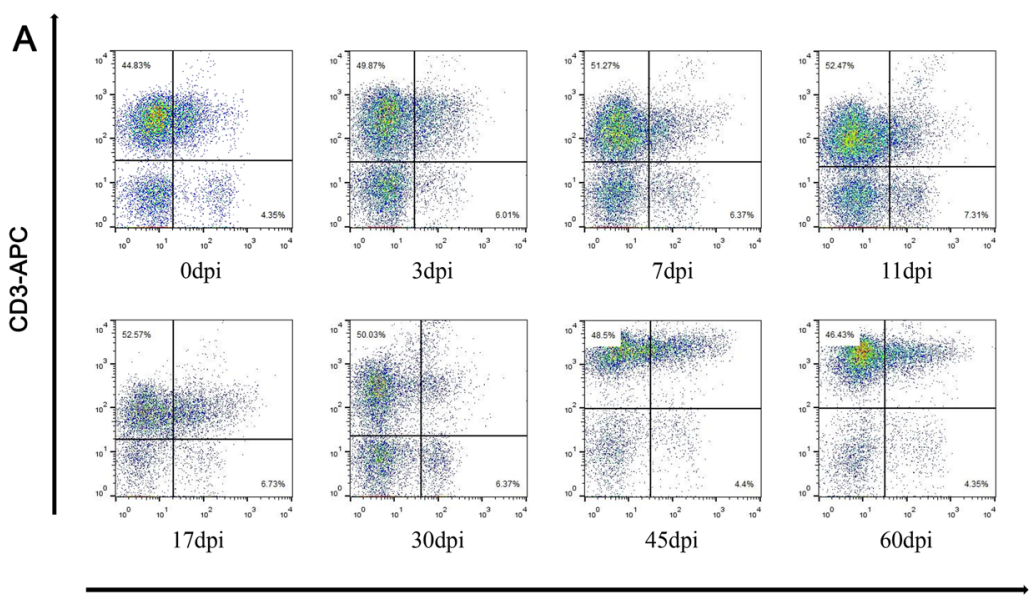

CD21-FITC
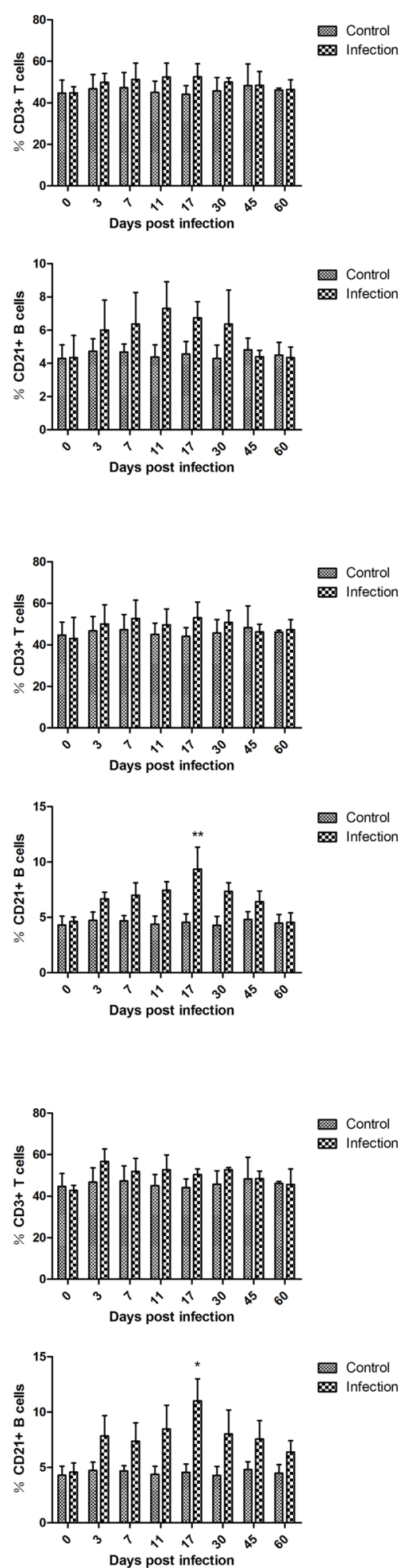

Control Infection

CD21-FITC
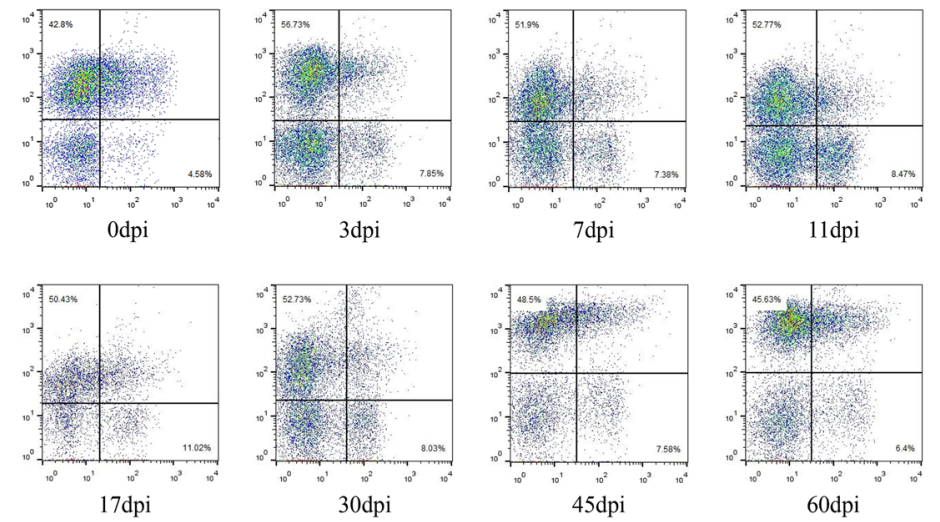

$60 \mathrm{dpi}$

Figure 1 Dynamics of CD3+T cells and CD21+ B cells during T. spiralis infection. Quantitative changes in CD3+T cells and CD21+ B cells in peripheral blood of pigs inoculated with 100 (A), 1000 (B), and 10000 (C) muscle larvae of T. spiralis, as analyzed by flow cytometry. The results shown are the means \pm SEMs of three independent pigs per group. ${ }^{*} P<0.05$ and ${ }^{*} P<0.01$, indicate statistically significant differences compared to the control group. 

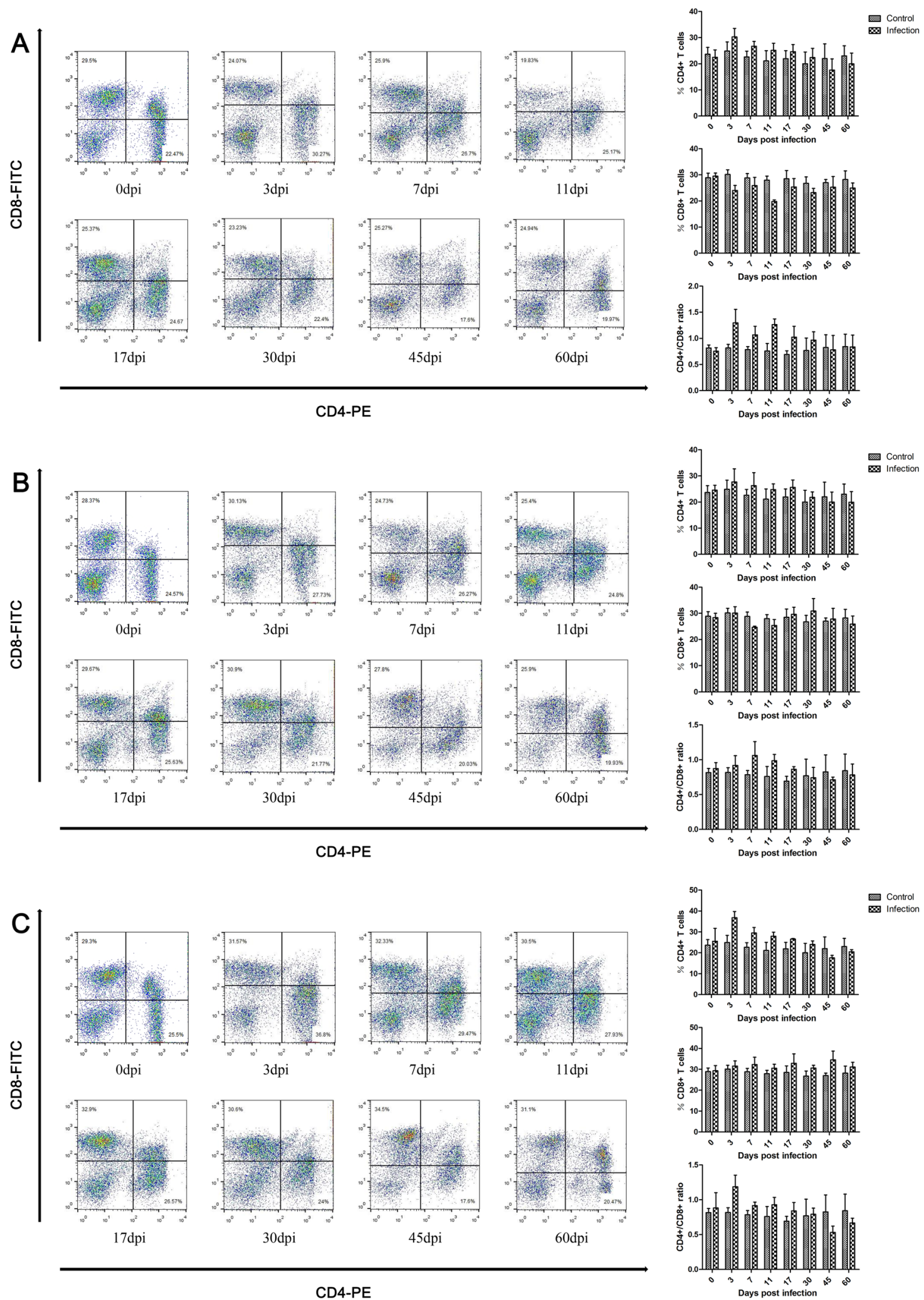

Figure 2 Dynamics of CD4+ T cells and CD8+ T cells during T. spiralis infection. Populations of CD4+ T cells and CD8+ T cells in peripheral blood of pigs inoculated with 100 (A), 1000 (B), and 10000 (C) muscle larvae of T. spiralis, as analyzed by flow cytometry. The results shown are the means \pm SEMs of three independent pigs per group. 


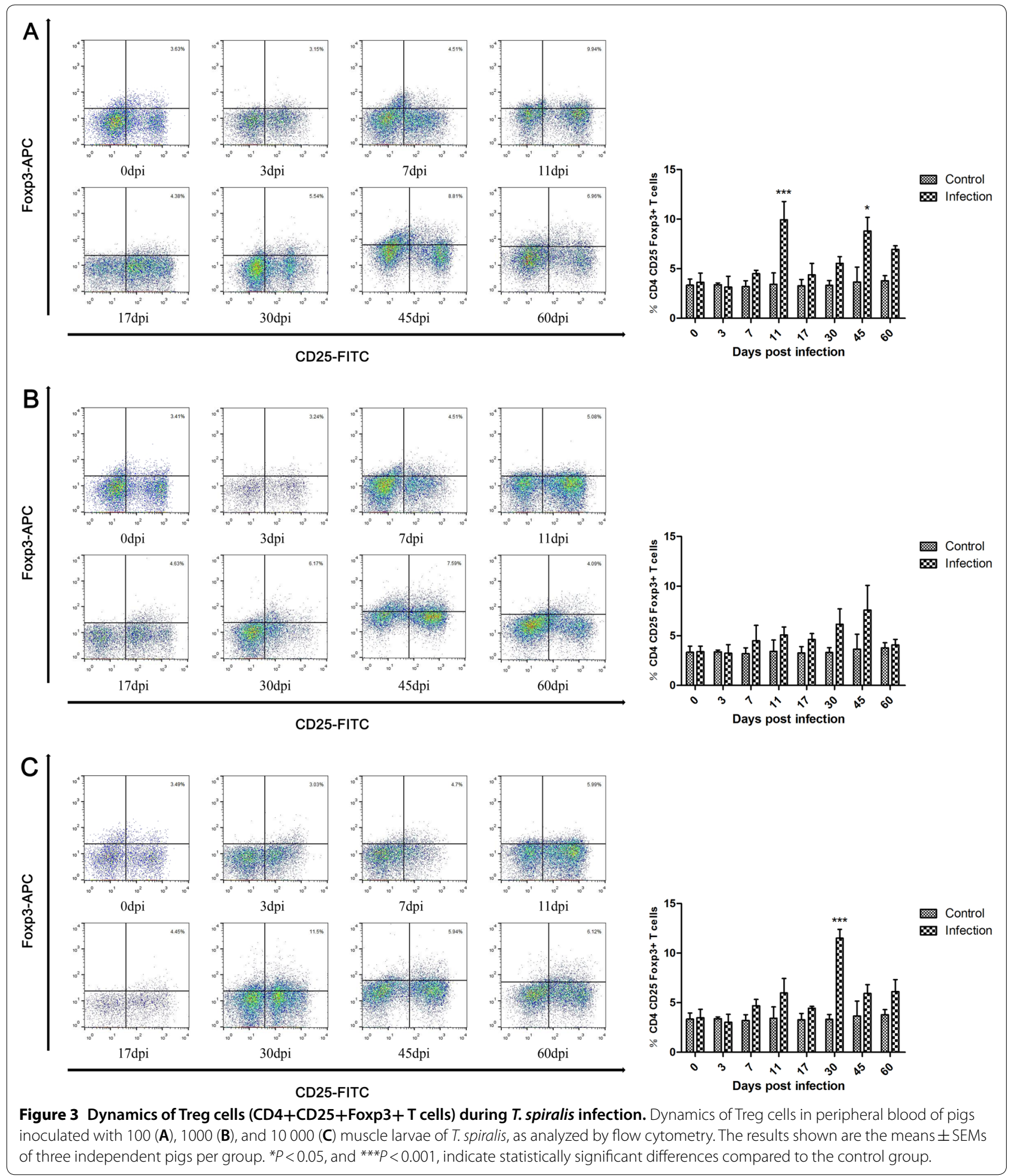

from the intestine. One explanation for this phenomenon is that nurse cell formation in the ML stage protected the parasite from specific antibody attack appearing after the fourth week of infection [12]. Another possibility is that the parasite could moderate the host immune response to facilitate parasite survival using secretory products and surface antigens $[12,17]$. In mice, the host immune response varies at different stages of $T$. spiralis infection 

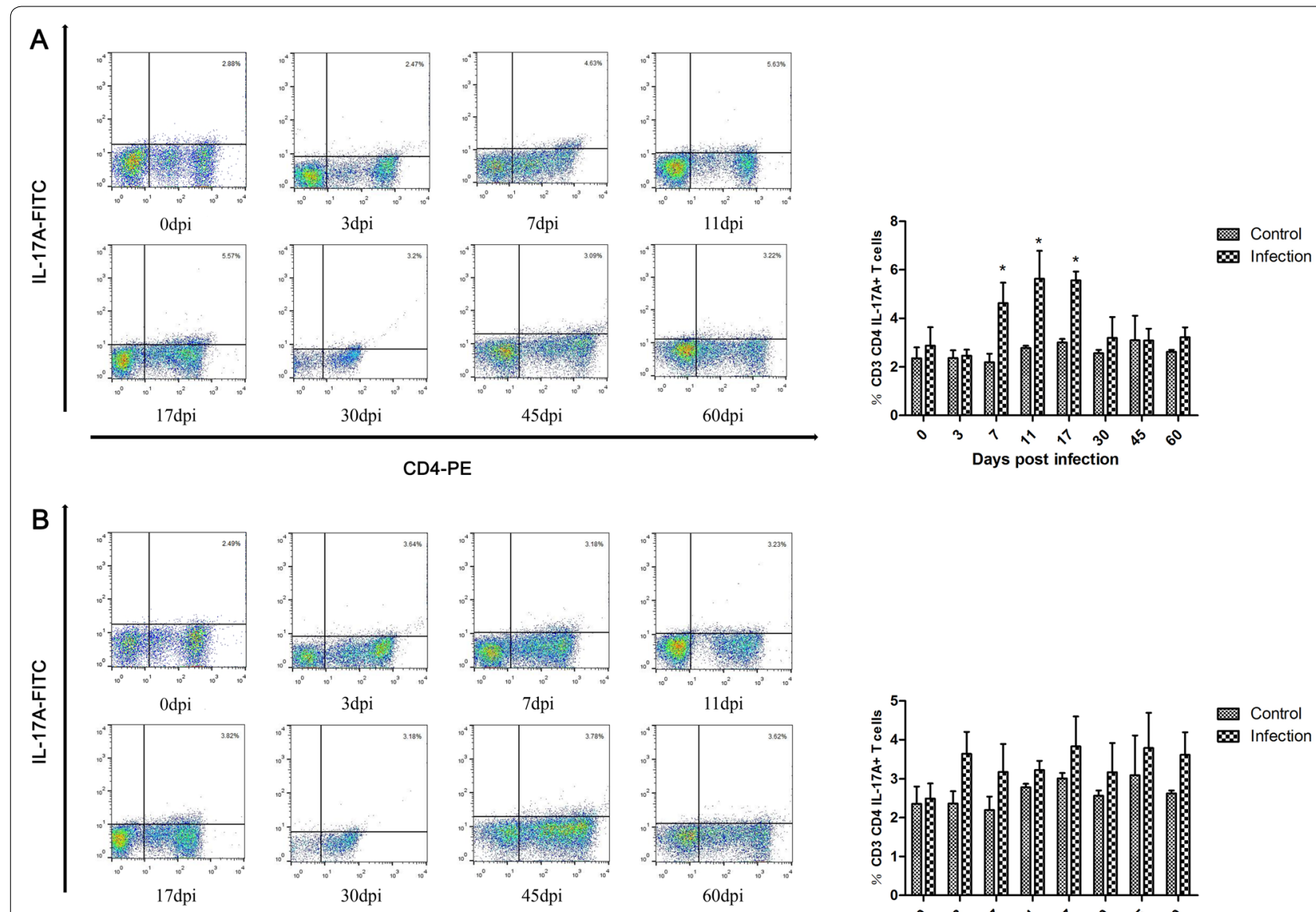

CD4-PE
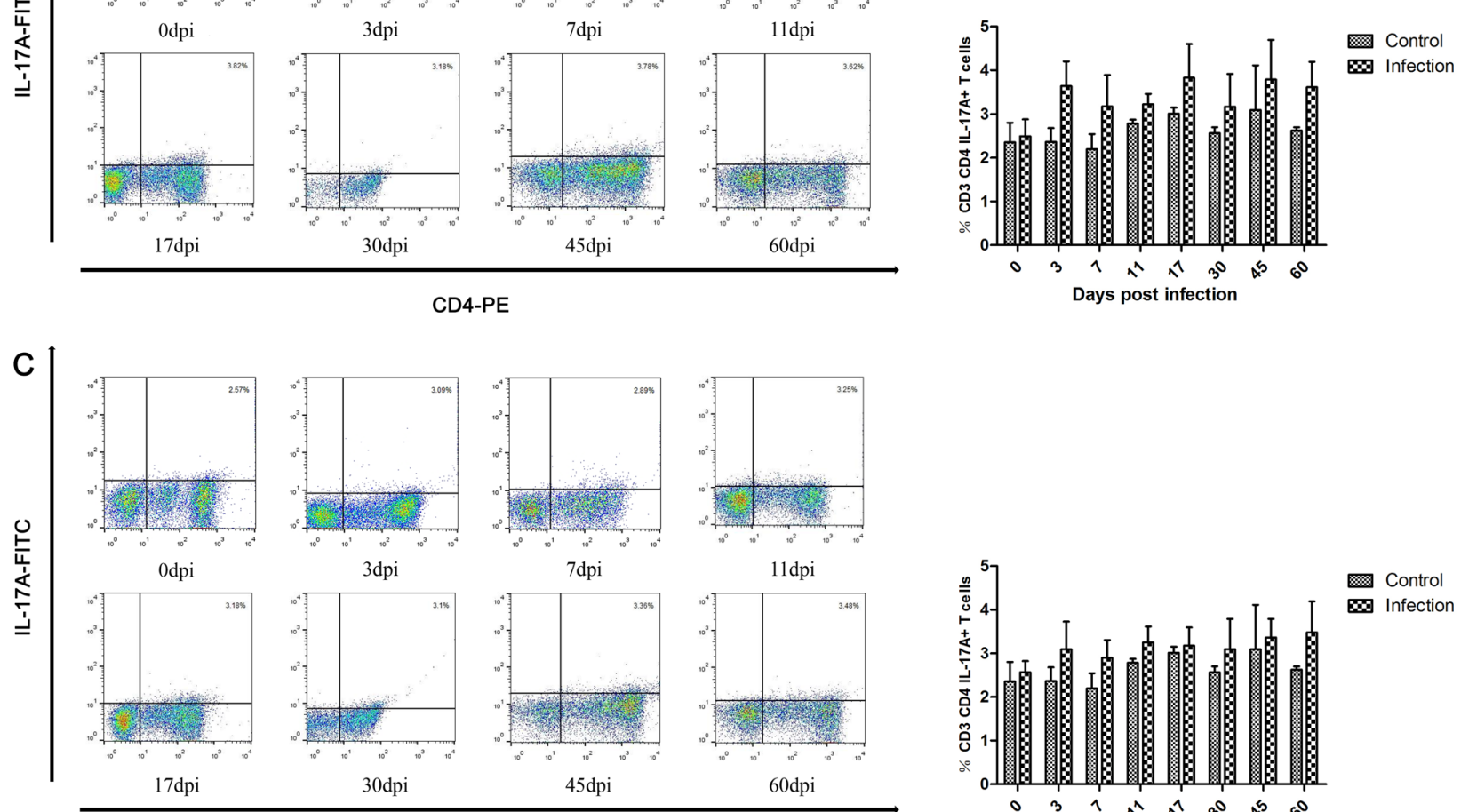

CD4-PE

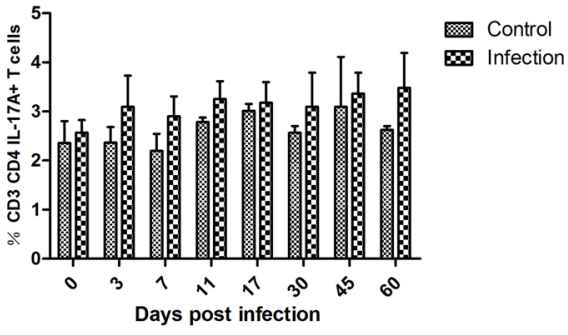

Figure 4 Dynamics of Th17 cells (CD3+CD4+IL-17A+ T cells) during T. spiralis infection. Dynamics of Th17 cells in peripheral blood of pigs inoculated with 100 (A), 1000 (B), and 10000 (C) muscle larvae of T. spiralis, as analyzed by flow cytometry. The results shown are the means \pm SEMs of three independent pigs per group. ${ }^{*} P<0.05$ indicates statistically significant differences compared to the control group.

[18]. However, the immune responses of mice and pigs are different [36]. This difference might prevent many potential candidates for vaccines and diagnostic targets with high protective efficacy and diagnostic efficacy in murine models from being applicable to pigs. In addition, the dynamics of immune cells and cytokines in pigs infected with $T$. spiralis have not been determined. Therefore, in this study, we characterized for the first 


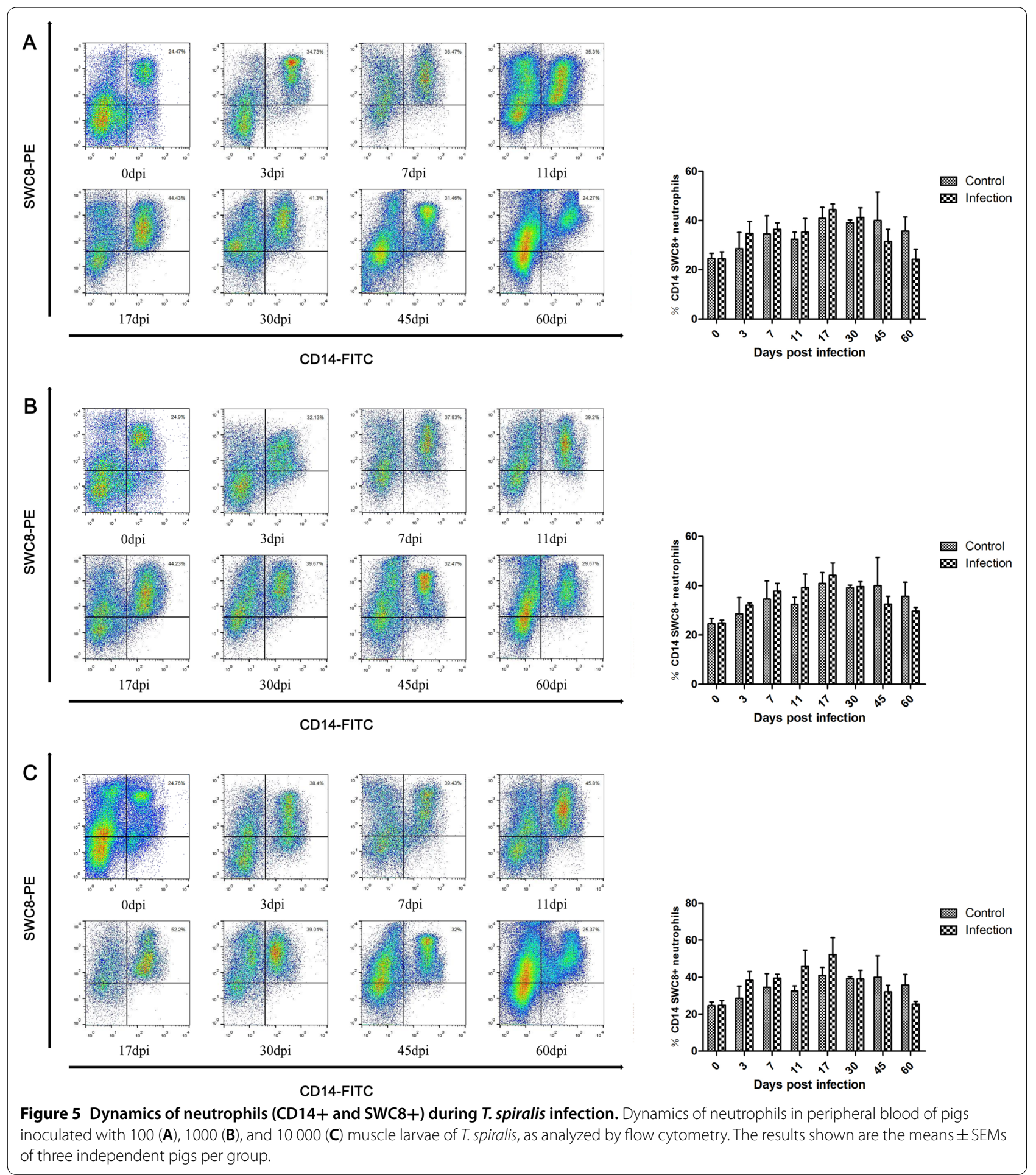

time the fundamental immunology of pigs infected with T. spiralis.

It was reported that ML can be detected in mice infected with doses as low as 5 L1 T. spiralis [37]. However, the body weight of pigs is significantly higher than that of mice; meanwhile, the pigs infected with 25 and $50 \mathrm{ML}$ exhibited few ML in the diaphragm and tongue of all animals (our unpublished data). Therefore, we increased the lowest infective dose to $100 \mathrm{ML}$, which was lower than that in a previous study, which employed 

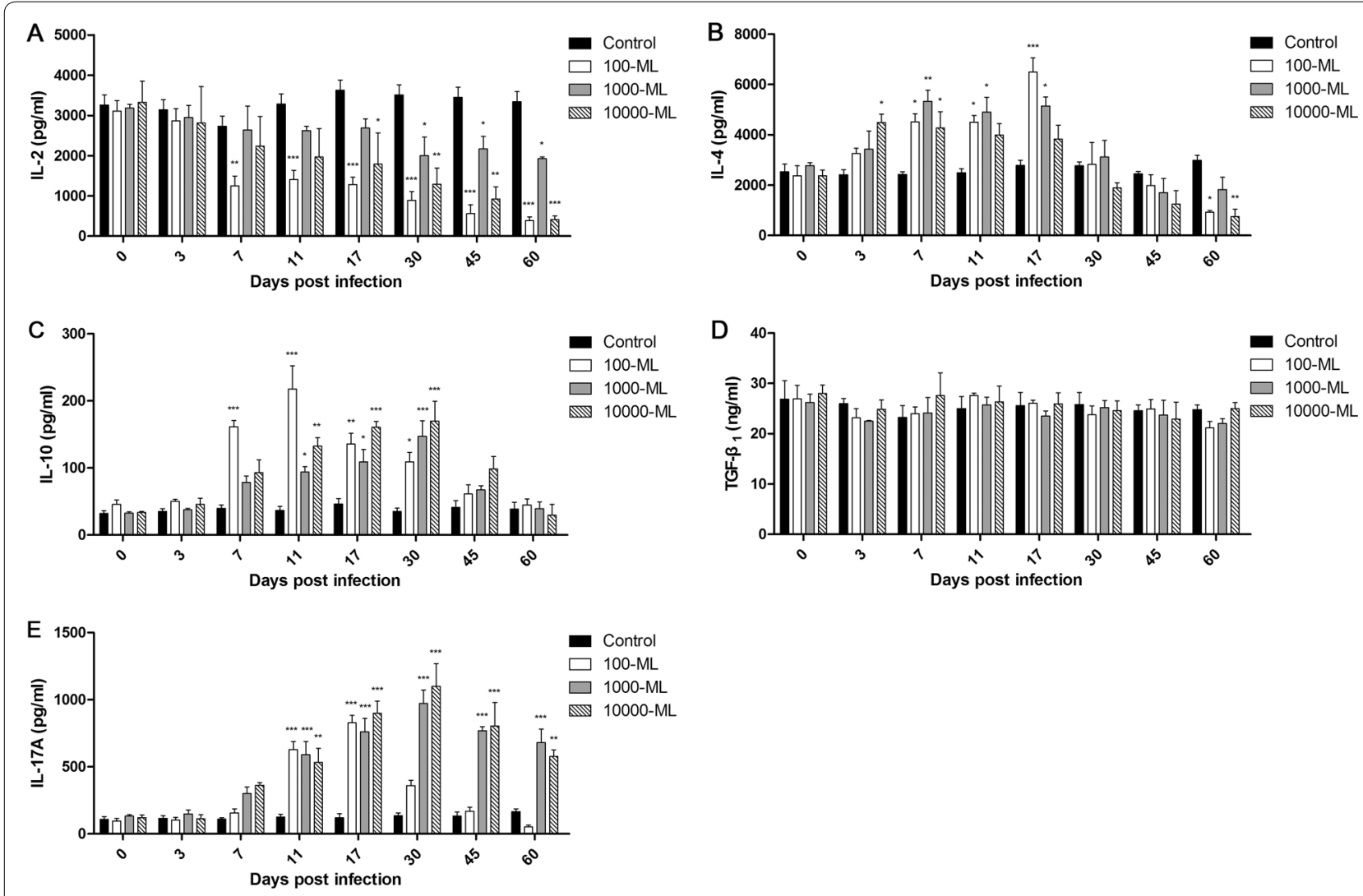

Figure 6 Cytokine expressions in T. spiralis-infected pigs. The levels of IL-2 (A), IL-4 (B), IL-10 (C), TGF- $\beta_{1}$ (D) and IL-17A (E) in serum of pigs inoculated with 100, 1000, and 10000 muscle larvae of T. spiralis were determined by ELISA. The results shown are the means \pm SEMs of three independent pigs per group. ${ }^{*} P<0.05,{ }^{*} P<0.01$, and ${ }^{* *} P<0.001$ indicate statistically significant differences compared to the control group.

$200 \mathrm{ML}$ as the lowest infection dose in pigs [38]. In this study, the results of artificial digestion of infected swine carcasses showed that all the infection groups were larvae-positive, even in the 100-ML infection groups. The intensity of recovered ML in muscle tissue was positively correlated with inoculated doses, and the RCI increased with inoculated doses. This suggested that the inoculated doses influence worm burden, which is consistent with the results of a previous study investigating horses and rats, even in long-term infection $[39,40]$. It is natural that increasing the infection dose increases ML burden due to increase of NBL. The lower RCI in the low-infective-dose group may be due to the presence of significant Th 2 and Treg immune responses, which suppress the Th1 immune response and promote worm expulsion [12, 20]. Meanwhile, a significant Th17 immune response in the low-infective-dose group participated in worm expulsion at the intestinal stage [26].

The cellular immune response plays a major role in parasite infection, affecting such cells as T cells, B cells, neutrophils, eosinophils, macrophages, mast cells, and goblet cells. $\mathrm{T}$ cells can perform two different functions by regulating the immune response: the worm expulsion and promoting worm survival. At the intestinal stage, the mechanisms of adult worm and NBL expulsion are mainly divided into the following points: the inflammatory response regulated by $\mathrm{T}$ helper cells plays a key role in the process of worm expulsion; a direct immune response to the stage-specific antigens; through the immunological mechanisms to worm expulsion [12]. NBL survival through stage-specific antigens and modifications of surface proteins, which cannot be bound to early specific antibodies for adult worms [41]. In addition, the lymphocytotoxic factors were released in NBL stage [12]. Anatomic seclusion was important to ML survival, and for the ML continuously releasing antigens to stimulate the host immune response in the muscle stage, the nurse cell protecting it from antibody and effector cell attack. To persistently survive in the host, the ML could modulate and suppress the host immune response [12]. In the muscle stage, the pathology of muscle mainly was damage in the myocardium, lungs and central nervous system caused by enriched eosinophils in the blood and tissues of the infected hosts [42]. 
The present study observed that the proportion of $\mathrm{T}$ cells was slightly elevated after infection and returned to basal levels sat later stages of infection. This finding was probably due to the rise of $\mathrm{CD} 4+\mathrm{T}$ cells in all infection groups and $\mathrm{CD} 8+\mathrm{T}$ cells in the high-dose group. CD4+ T cells are generated in the intestinal phase of $T$. spiralis after 2-4 dpi and play a key role in the immune response $[43,44]$. Our results showed that $C D 4+T$ cells increased after infection and peaked at $3 \mathrm{dpi}$, which was similar to the results obtained by previous studies [43, 44]. Diarrhea was observed in humans at the intestinal phase of the infection due to inflammation caused by adult worms migrating to Peyer's patches and development and continuous antigen stimulation exposure to the host [45]. The immune response was important to adult worm expulsion at the intestinal phase, which was dependent on CD4+ T cells [46]. However, the proportions of $\mathrm{CD} 4+\mathrm{T}$ cells were lower in the infected group after $45 \mathrm{dpi}$. It may be that the immunomodulation strategy induced by Treg immune response in T. spiralis infection, which is able to tame the Th1, Th2, and Th17 immune responses [17]. Consequently, the proportions of CD4+ T cells were reduced in the muscle stage. CD8+ $\mathrm{T}$ cells play a key role in worm expulsion by the subset of CD8+ cytotoxic T cells (Tc), which could activate mononuclear phagocytes to kill parasites [47]. In the lower and middle infection groups, CD8 $+\mathrm{T}$ cells were suppressed by infection with $T$. spiralis, and this suppression was important to parasite survival at the intestinal phase. However, the number of CD8+ T cells was increased in the highest-dose infection group after infection, possibly because large numbers of worms cause severe damage and inflammation in the intestinal and muscle tissues, which triggers an expulsion worm response. It has been reported that both $\mathrm{CD} 4+$ and $\mathrm{CD} 8+\mathrm{T}$ cells were increased in infected mice with $500 \mathrm{ML}$, and the levels of $\mathrm{CD} 8+\mathrm{T}$ cells were increased higher than CD4+ T cells and with a declining ratio of CD4+/CD8+ T cells [43]. In our study, the ratio of CD4+/CD8+ T cells was elevated at the intestinal phase, which meant that the most serious suppression of the immune response occurred during the intestinal phase of pigs infected with $T$. spiralis. The results indicated that the immune response process of pigs and mice was different during infection with $T$. spiralis.

Previous studies demonstrated that the immune system of rodents and humans infected with $T$. spiralis is driven to a less dangerous response, in which Th2 was predominant with a short Th1 immune response [10, 12]. The Th2 immune response was induced in parasitic infections to inhibit Th1 activation. In humans, the Th2 immune response persists in chronic infection of T. spiralis, which is important to the protective immune response [11]. IL-4 is involved in protective Th2 immune responses and promotes the production of IgE, which is a Th2-associated humoral response [48, 49]. The aim of the Th1-type immune response is to eliminate the parasite. However, this response damages the host, which favors the survival of the parasite [20]. The Th1 type cytokine IL-12 delays worm expulsion and increases worm burden in an IFNy-independent manner [50]. The Th2 immune response induced by $T$. spiralis infection plays a key role in intestinal immunity for adult worm expulsion [12]. In our study, the inhibition of the Th1 immune response was accompanied by an elevation of the Th2 immune response at $7 \mathrm{dpi}$, which promoted adult worm expulsion at the intestinal stage. The results indicated that down regulation of the Th1 immune response may be due to Th2 immune response activation. Although the worm expulsion existed at the intestinal phase of the infection, the parasite could modulate and suppress the immune response by secreting antigens to escape from the host immune response $[12,51]$. The parasite stimulates the production of Treg cells to homeostatic inflammation responses of hosts [52]. At the early stages of muscle infection, Treg cytokine IL-10 is able to limit local and regional inflammation, and TGF- $\beta$ also regulates local inflammation response in infected muscle, which facilitates NBL and ML survival. Conversely, depletion of Treg cells results in exaggerated Th2 responses $[53,54]$. Meanwhile, immunomodulation of T. spiralis infection has a therapeutic effect on chronic autoimmune diseases, such as colitis and encephalomyelitis (EAE) [55, 56]. In this study, the activation of the Treg immune response begins at $7 \mathrm{dpi}$ and maintains high levels when encapsulation is formed, which is important to control the inflammatory response and NBL and ML survival at the intestinal and muscle stages. The above theory was confirmed by our results indicating that the levels of Th2 and Treg cells were significantly increased after pigs were infected with $T$. spiralis, and Th1 cell levels declined, which was different from the results obtained in rodents and humans with a short Th1 immune response $[10,12]$. Interestingly, the immune responses regulated in $T$. spiralis infection had a focus on the NBL production phase. It may be that the worms have different developmental stages and born larvae at the intestinal phase, releasing stage-specific antigens and surface antigens that are frequently exposed to hosts, inducing the immune response. Immunomodulation was decreased when nurse cells formed. The most obvious immune regulation occurs in low-dose infection groups, which cannot be explained at present and warrants further investigation. 
Other inflammatory cells, such as neutrophils and Th17 cells, were increased in the peripheral blood of infected pigs. Neutrophils play a key role in the innate immune system responses, which are able to phagocytose foreign matter [29]. The functions of neutrophils were to promote inflammation and fight infections. In the present study, neutrophils increased after infection and peaked at $17 \mathrm{dpi}$, which may be associated with expulsion worms by killing NBL in antibody-dependent cell-mediated cytotoxicity (ADCC) systems [57, 58]. It was reported that the levels of IL-17A, which is involved in the activation of Th17 cells, were increased during the intestinal phase of $T$. spiralis infection, IL$17 \mathrm{~A}$ is a pro-inflammatory mediator and contributes to jejunal muscle contractility that may contribute to parasite expulsion from the gut [26]. IL-17A promotes the increased number of neutrophils in the airways [59]. Our results indicated a similar increase in pigs infected with $T$. spiralis. However, the levels of IL-17A were significantly higher than the proportion of the Th17 cells, and the changes of Th17 cells in lower infection doses were significant than higher infection doses. The mechanism underlying the regulation of Th17 cells warrants further investigation.

Humoral responses were induced by T. spiralis in the immune response of hosts [17]. Antibodies were the key component of humoral immunity produced by $\mathrm{B}$ cells. The IgG antibodies can kill the NBL by induced eosinophils and ADCC [43]. A previous study demonstrated that the number of $\mathrm{B}$ cells significantly increased at $15 \mathrm{dpi}$ in mice infected with $T$. spiralis [43]. Our results showed that B cells were significantly increased in the middle-dose and high-dose groups at $17 \mathrm{dpi}$, which was similar to the results of a previous study in mice [43]. Meanwhile, as the infection dose increased, the production and maintenance time of $\mathrm{B}$ cells also increased. This finding may be attributable to high doses of infection with large amounts of secretory antigens and surface antigens exposure for the host to continuously stimulate the proliferation of B cells.

In conclusion, based on these findings, T. spiralis achieves successful parasitism by regulating the immune response of the host. Our results confirmed that pigs infected with $T$. spiralis predominantly induced Th2 and Treg immune responses, which suppress the Th1 immune response. These observations provide a valuable information for further study of the immunology and parasitology between pigs and parasites and are important for the diagnosis and treatment of $T$. spiralis infection.

\section{Abbreviations}

ELISA: enzyme-linked immunosorbent assay; ANOVA: analysis of variance; ML: muscle larvae; Ad: adult worm; NBL: new born larvae; dpi: days post-infection; Ipg: larvae per gram; IL: interleukin; TGF- $\beta$ : transforming growth factor-beta; ADCC: antibody-dependent cell-mediated cytotoxicity; Tc: cytotoxic T cells; APCs: antigen-presenting cells; $\mathrm{RCl}$ : reproductive capacity index; SWC8: swine workshop cluster number 8 .

\section{Acknowledgements}

We thank Prof. Xuejin Su, Key Laboratory of Pathobiology, Ministry of Education, for providing us with technical assistance. Our thanks are also extended to express our gratitude to all the people who made this work.

\section{Authors' contributions}

NW and XB carried out the literature search and drafted the first version of the manuscript. BT and $Y Y$ were responsible for designing and analyzed the data. XW, HZ, XL, HY, HJ and NW performed the experiments and assisted on the sample collections. $M L$ and $X L$ revised the review. All authors read and approved the final manuscript.

\section{Funding}

This study was supported by The National Key Research and Development Program of China (2017YFD0501300), the National Natural Science Foundation of China (31520103916, 31872467), Guangdong Innovative and Enterpreneurial Research Team Program (NO. 2014ZT05S123) and Program for JLU Science and Technology Innovative Research Team.

\section{Availability of data and materials}

All data generated or analyzed during this study are included in this published article.

\section{Ethics approval and consent to participate}

All experiments in this study were conducted according to the regulations of the Administration of Affairs Concerning Experimental Animals in China. The procedure of animal experiments was approved by the Institutional Animal Care and Use Committee of Jilin University (No. 20170318).

\section{Competing interests}

The authors declare that they have no competing interests.

\section{Author details}

${ }^{1}$ Key Laboratory of Zoonosis Research, Ministry of Education, Institute of Zoonosis/College of Veterinary Medicine, Jilin University, Changchun 130000, China. ${ }^{2}$ Institute of Animal Sciences, Chinese Academy of Agricultural Sciences, Beijing 100193, China. ${ }^{3}$ State Key Laboratory of Veterinary Etiological Biology, Key Laboratory of Veterinary Parasitology of Gansu Province, Lanzhou Veterinary Research Institute, Chinese Academy of Agricultural Sciences, Lanzhou 730046, China.

Received: 12 November 2019 Accepted: 20 January 2020

Published online: 21 February 2020

\section{References}

1. Gottstein B, Pozio E, Nockler K (2009) Epidemiology, diagnosis, treatment, and control of trichinellosis. Clin Microbiol Rev 22:127-145

2. Loreck K, Mitrenga S, Meemken D, Heinze R, Reissig A, Mueller E, Ehricht R, Engemann C, Greiner M (2019) Development of a miniaturized protein microarray as a new serological lgG screening test for zoonotic agents and production diseases in pigs. PLoS One 14:e0217290

3. Cui J, Wang ZQ (2011) An epidemiological overview of swine trichinellosis in China. Vet J 190:323-328

4. Wang ZQ, Ren HJ, Li LZ, Cui J (2015) Clinical and etiological study of a small familiar outbreak of trichinellosis in Tibet, China. Helminthologia 52:130-133

5. Rawla P, Sharma S (2019) Trichinella Spiralis (Trichnellosis). StatPearls, Treasure Island

6. Cui J, Jiang P, Liu LN, Wang ZQ (2013) Survey of Trichinella infections in domestic pigs from Northern and Eastern Henan, China. Vet Parasitol 194:133-135 
7. Jiang $P$, Zhang $X$, Wang $L A$, Han $L H$, Yang M, Duan JY, Sun GG, Qi X, Liu RD, Wang ZQ, Cui J (2016) Survey of Trichinella infection from domestic pigs in the historical endemic areas of Henan province, central China. Parasitol Res 115:4707-4709

8. Brodaczewska K, Wolaniuk N, Lewandowska K, Donskow-Lysoniewska K, Doligalska M (2017) Biodegradable chitosan decreases the immune response to Trichinella spiralis in mice. Molecules 22:E2008

9. Wu Z, Nagano I, Takahashi Y, Maekawa Y (2016) Practical methods for collecting Trichinella parasites and their excretory-secretory products. Parasitol Int 65:591-595

10. Della Bella C, Benagiano M, De Gennaro M, Gomez-Morales MA, Ludovisi A, D'Elios S, Luchi S, Pozio E, D'Elios MM, Bruschi F (2017) T-cell clones in human trichinellosis: evidence for a mixed Th1/Th2 response. Parasite Immunol 39:e12412

11. Morales MA, Mele R, Sanchez M, Sacchini D, De Giacomo M, Pozio E (2002) Increased CD8(+)-T-cell expression and a type 2 cytokine pattern during the muscular phase of Trichinella infection in humans. Infect Immun 70:233-239

12. Bruschi F, Chiumiento $L$ (2012) Immunomodulation in trichinellosis: does Trichinella really escape the host immune system? Endocr Metab Immune Disord Drug Targets 12:4-15

13. Qu Z, Li W, Zhang N, Li L, Yan H, Li T, Cui J, Yang Y, Jia W, Fu B (2019) Comparative genomic analysis of Trichinella spiralis reveals potential mechanisms of adaptive evolution. Biomed Res Int 2019:2948973

14. Ren HN, Liu RD, Song YY, Zhuo TX, Guo KX, Zhang Y, Jiang P, Wang ZQ, Cui I (2019) Label-free quantitative proteomic analysis of molting-related proteins of Trichinella spiralis intestinal infective larvae. Vet Res 50:70

15. Zarowiecki M, Berriman M (2015) What helminth genomes have taught us about parasite evolution. Parasitology 142(Suppl 1):S85-97

16. Nagano I, Wu Z, Nakada T, Matsuo A, Takahashi Y (2001) Molecular cloning and characterization of a serine proteinase inhibitor from Trichinella spiralis. Parasitology 123:77-83

17. Sofronic-Milosavljevic L, llic N, Pinelli E, Gruden-Movsesijan A (2015) Secretory products of Trichinella spiralis muscle larvae and immunomodulation: implication for autoimmune diseases, allergies, and malignancies. J Immunol Res 2015:523875

18. Ding J, Bai X, Wang X, Shi H, Cai X, Luo X, Liu M, Liu X (2017) Immune cell responses and cytokine profile in intestines of mice infected with Trichinella spiralis. Front Microbiol 8:2069

19. Yu YR, Deng MJ, Lu WW, Jia MZ, Wu W, Qi YF (2013) Systemic cytokine profiles and splenic toll-like receptor expression during Trichinella spiralis infection. Exp Parasitol 134:92-101

20. Munoz-Carrillo JL, Contreras-Cordero JF, Munoz-Lopez JL, MaldonadoTapia CH, Munoz-Escobedo JJ, Moreno-Garcia MA (2017) Resiniferatoxin modulates the Th1 immune response and protects the host during intestinal nematode infection. Parasite Immunol 39:e12448

21. Maizels RM, Gause WC (2014) Immunology. How helminths go viral. Science 345:517-518

22. Maizels RM, Yazdanbakhsh M (2008) T-cell regulation in helminth parasite infections: implications for inflammatory diseases. Chem Immunol Allergy 94:112-123

23. Ilic N, Gruden-Movsesijan A, Sofronic-Milosavljevic L (2012) Trichinella spiralis: shaping the immune response. Immunol Res 52:111-119

24. Mbow M, Larkin BM, Meurs L, Wammes $L$, de Jong SE, Labuda LA, Camara M, Smits HH, Polman K, Dieye TN, Mboup S, Stadecker MJ, Yazdanbakhsh M (2013) T-helper 17 cells are associated with pathology in human schistosomiasis. J Infect Dis 207:186-195

25. Yen D, Cheung J, Scheerens H, Poulet F, McClanahan T, McKenzie B, Kleinschek MA, Owyang A, Mattson J, Blumenschein W, Murphy E, Sathe M, Cua DJ, Kastelein RA, Rennick D (2006) IL-23 is essential for T cell-mediated colitis and promotes inflammation via IL-17 and IL-6. J Clin Invest 116:1310-1316

26. Fu Y, Wang W, Tong J, Pan Q, Long Y, Qian W, Hou X (2009) Th17: a new participant in gut dysfunction in mice infected with Trichinella spiralis. Mediators Inflamm 2009:517052

27. Meding SJ, Langhorne J (1991) CD4+T cells and B cells are necessary for the transfer of protective immunity to Plasmodium chabaudi chabaudi. Eur J Immunol 21:1433-1438

28. Flores-Borja F, Bosma A, Ng D, Reddy V, Ehrenstein MR, Isenberg DA, Mauri C (2013) CD19+ CD24hiCD38hi B cells maintain regulatory T cells while limiting TH1 and TH17 differentiation. Sci Transl Med 5:173ra123
29. Jablonska J, Granot Z (2017) Neutrophil, quo vadis? J Leukoc Biol 102:685-688

30. Tillack K, Breiden P, Martin R, Sospedra M (2012) T lymphocyte priming by neutrophil extracellular traps links innate and adaptive immune responses. J Immunol 188:3150-3159

31. Thewissen M, Damoiseaux J, van de Gaar J, Tervaert JW (2011) Neutrophils and T cells: bidirectional effects and functional interferences. Mol Immunol 48:2094-2101

32. Li JF, Guo KX, Qi X, Lei JJ, Han Y, Yan SW, Jiang P, Yu C, Cheng XC, Wang ZQ, Cui J (2018) Protective immunity against Trichinella spiralis in mice elicited by oral vaccination with attenuated Salmonella-delivered TsSP1.2 DNA. Vet Res 49:87

33. Qi X, Han Y, Jiang P, Yue X, Ren HN, Sun GG, Long SR, Yu C, Cheng XC, Cui J, Wang ZQ (2018) Oral vaccination with Trichinella spiralis DNase II DNA vaccine delivered by attenuated Salmonella induces a protective immunity in BALB/C mice. Vet Res 49:119

34. Li F, Cui J, Wang ZQ, Jiang P (2010) Sensitivity and optimization of artificial digestion in the inspection of meat for Trichinella spiralis. Foodborne Pathog Dis 7:879-885

35. Yang Y, Bai X, Li C, Tong M, Zhang P, Cai W, Liu X, Liu M (2019) Molecular characterization of fructose-1,6-bisphosphate aldolase from Trichinella spiralis and its potential in inducing immune protection. Front Cell Infect Microbiol 9:122

36. Zhang N, Li W, Fu B (2018) Vaccines against Trichinella spiralis: progress, challenges and future prospects. Transbound Emerg Dis 65:1447-1458

37. Reiterova K, Antolova D, Hurnikova Z (2009) Humoral immune response of mice infected with low doses of Trichinella spiralis muscle larvae. Vet Parasitol 159:232-235

38. Nockler K, Serrano FJ, Boireau P, Kapel CM, Pozio E (2005) Experimental studies in pigs on Trichinella detection in different diagnostic matrices. Vet Parasitol 132:85-90

39. Hill DE, Forbes L, Kramer M, Gajadhar A, Gamble HR (2007) Larval viability and serological response in horses with long-term Trichinella spiralis infection. Vet Parasitol 146:107-116

40. Franssen FF, Fonville M, Takumi K, Vallee I, Grasset A, Koedam MA, Wester PW, Boireau P, van der Giessen JW (2011) Antibody response against Trichinella spiralis in experimentally infected rats is dose dependent. Vet Res 42:113

41. Jungery M, Clark NW, Parkhouse RM (1983) A major change in surface antigens during the maturation of newborn larvae of Trichinella spiralis. Mol Biochem Parasitol 7:101-109

42. Bruschi F, Korenaga M, Watanabe N (2008) Eosinophils and Trichinella infection: toxic for the parasite and the host? Trends Parasitol 24:462-467

43. Ding J, Bai X, Wang XL, Wang YF, Shi HN, Rosenthal B, Boireau P, Wu XP, Liu MY, Liu XL (2016) Developmental profile of select immune cells in mice infected with Trichinella spiralis during the intestinal phase. Vet Parasitol 231:77-82

44. Korenaga M, Wang CH, Bell RG, Zhu D, Ahmad A (1989) Intestinal immunity to Trichinella spiralis is a property of OX8-OX22-T-helper cells that are generated in the intestine. Immunology 66:588-594

45. Viallet J, MacLean JD, Goresky CA, Staudt M, Routhier G, Law C (1986) Arctic trichinosis presenting as prolonged diarrhea. Gastroenterology 91:938-946

46. Riedlinger J, Grencis RK, Wakelin D (1986) Antigen-specific T-cell lines transfer protective immunity against Trichinella spiralis in vivo. Immunology 58:57-61

47. Annunziato F, Romagnani C, Romagnani S (2015) The 3 major types of innate and adaptive cell-mediated effector immunity. J Allergy Clin Immunol 135:626-635

48. Ierna MX, Scales HE, Saunders KL, Lawrence CE (2008) Mast cell production of IL-4 and TNF may be required for protective and pathological responses in gastrointestinal helminth infection. Mucosal Immunol 1:147-155

49. Finkelman FD, Katona IM, Urban JF Jr, Snapper CM, Ohara J, Paul WE (1986) Suppression of in vivo polyclonal lgE responses by monoclonal antibody to the lymphokine B-cell stimulatory factor 1. Proc Natl Acad Sci U S A 83:9675-9678

50. Helmby H, Grencis RK (2003) IFN-gamma-independent effects of IL-12 during intestinal nematode infection. J Immunol 17:3691-3696

51. Watanabe N, Bruschi F, Korenaga M (2005) IgE: a question of protective immunity in Trichinella spiralis infection. Trends Parasitol 21:175-178 
52. Belkaid $Y$, Sun CM, Bouladoux N (2006) Parasites and immunoregulatory $T$ cells. Curr Opin Immunol 18:406-412

53. Beiting DP, Bliss SK, Schlafer DH, Roberts VL, Appleton JA (2004) Interleukin-10 limits local and body cavity inflammation during infection with muscle-stage Trichinella spiralis. Infect Immun 72:3129-3137

54. Beiting DP, Gagliardo LF, Hesse M, Bliss SK, Meskill D, Appleton JA (2007) Coordinated control of immunity to muscle stage Trichinella spiralis by IL-10, regulatory T cells, and TGF-beta. J Immunol 178:1039-1047

55. Jin X, Yang Y, Bai X, Shi H, Zhang W, Zhang Z, Jia W, Lin J, Liu M, Liu X (2019) Dendritic cells treated by Trichinella spiralis muscle larval excretory/ secretory products alleviate TNBS-induced colitis in mice. Int Immunopharmacol 70:378-386

56. Gruden-Movsesijan A, Ilic N, Mostarica-Stojkovic M, Stosic-Grujicic S, Milic M, Sofronic-Milosavljevic L (2008) Trichinella spiralis: modulation of experimental autoimmune encephalomyelitis in DA rats. Exp Parasitol 118:641-647
57. Bruschi F (2004) Focus on immunology of trichinellosis. Med Chem Rev 1:179-185

58. Ren HN, Guo KX, Zhang Y, Sun GG, Liu RD, Jiang P, Zhang X, Wang L, Cui J, Wang ZQ (2018) Molecular characterization of a $31 \mathrm{kDa}$ protein from Trichinella spiralis and its induced immune protection in BALB/C mice. Parasit Vectors 11:625

59. Linden A, Hoshino H, Laan M (2000) Airway neutrophils and interleukin-17. Eur Respir J 15:973-977

\section{Publisher's Note}

Springer Nature remains neutral with regard to jurisdictional claims in published maps and institutional affiliations.
Ready to submit your research? Choose BMC and benefit from:

- fast, convenient online submission

- thorough peer review by experienced researchers in your field

- rapid publication on acceptance

- support for research data, including large and complex data types

- gold Open Access which fosters wider collaboration and increased citations

- maximum visibility for your research: over $100 \mathrm{M}$ website views per year

At BMC, research is always in progress.

Learn more biomedcentral.com/submissions 